\title{
Sporcularda D Vitamininin Fiziksel Performans Üzerindeki Önemi
}

Büşra DEMİRER1, Ayşe ŞİMŞEK2, Musa GÜNEŞ2

ORIJIINAL ARAŞTIRMA

1 Karabük Üniversitesi, Sağlık Bilimleri Fakültesi, Beslenme ve Diyetetik Bölümü,

Karabük/Türkiye

2 Karabük Üniversitesi, Sağllk Bilimleri Fakültesi, Fizyoterapi ve Rehabilitasyon Bölümü, Karabük/Türkiye

\section{Sorumlu Yazar: \\ Büşra DEMİRER}

Orcid ID: 0000-0003-1945-0485

\section{Yayın Bilgisi \\ Gönderi Tarihi: \\ 29.04.2020 \\ Kabul Tarihi: \\ 08.06.2020 \\ Online Yayın Tarihi: \\ 28.06.2020}

Doi: 10.38021 asbid.729441

\section{$\ddot{\mathbf{O z}}$}

Bu çalışmanın amacı sporcularda D vitamininin fiziksel performans üzerindeki önemine dair yapılmış çalışmaların değerlendirilmesidir. $\mathrm{Bu}$ amaçla PubMed, Google Scholar, ScienceDirect veritabanlarında 'Vitamin D and athlete', 'Vitamin D and athlete health', 'Vitamin D and athlete performance' ve 'D vitamini ve sporcu' anahtar kelimeleri ile tarama yapılarak yayınlanan araştırmalar çalışmanın amacına uygun şekilde incelenmiştir. D vitamini yağda eriyen vitaminler grubunda olup aynı zamanda endojen olarak sentezlenebildiği için hormon ve hormon benzeri işlevlere sahip sterol türevidir. D vitamininin birincil kaynağı, ultraviyole B ışınını içeren güneş 1şığıdır. Besinlerle alınan D vitamini yetersiz gelmektedir ve D vitamini eksikliği dünya çapında yaygın bir halk sağlı̆̆ sorunudur. D vitamini eksikliği kas-iskelet sistemi hastalıkları başta olmak üzere birçok sağlık problemi ile ilişkilendirilmektedir. Sporcularda yapılan araştırmalarda, D vitamininin fiziksel performans üzerindeki potansiyel ergojenik etkilerine odaklanılmıştır. Bu noktada kas dokusunda D vitamini reseptörünün bulunması önem taşımaktadır. Yapılan çalışmalarda D vitamini eksikliğinin, kuvvet kaybına yol açabileceği ve fiziksel performans ile olumsuz ilişkili olduğu tespit edilen tip II kas liflerinde dejenerasyona yol açabileceği bildirilmiştir. D vitamini takviyesinin D vitamini durumunu iyileştirdiği, kas kuvvetini artırdığı ve fiziksel aktivite seviyesinde artış sağladığı gösterilmiştir. Ancak yapılan çalışmaların büyük kısmı genel popülasyonda yürütülmüştür. Sporcularda D vitamini durumu ve fiziksel performans arasındaki ilişki az sayıda çalışma ile incelenmiştir. Sonuç olarak insan iskelet kası dokusunda kalsitriol etkisinin altında yatan mekanizmaları tam olarak karakterize etmek ve bu eylemlerin sporculardaki fiziksel performansı nasıl etkilediğini anlamak için daha fazla çalışma gereklidir.

Anahtar kelimeler: D vitamini, Fiziksel Performans, Kas Kuvveti, Spor

\section{The Importance of Vitamin D on Physical Performance in} Athletes

\section{Abstract}

The aim of this study is to evaluate the studies on the importance of vitamin D on physical performance in athletes. For this purpose, the studies published in PubMed, Google Scholar, ScienceDirect databases with the keywords 'Vitamin D and athlete', 'Vitamin D and athlete health', and 'Vitamin D and athlete performance' were examined in accordance with the purpose of the study. . Vitamin D is a sterol derivative with hormone and hormone-like functions since it is in the group of fat-soluble vitamins and can also be synthesized endogenously. The primary source of vitamin D is sunlight containing ultraviolet B rays. Vitamin D taken with nutrients is inadequate and vitamin D deficiency is a common public health problem worldwide. Vitamin D deficiency is associated with many health problems, especially musculoskeletal diseases. Research in athletes focused on the potential ergogenic effects of vitamin D on physical performance. At this point, it is important to have a vitamin $\mathrm{D}$ receptor in muscle tissue. Studies have reported that vitamin D deficiency can lead to loss of strength and lead to degeneration in type II muscle fibers that have been found to be negatively related to physical performance. Vitamin D supplements have been shown to improve vitamin D status, increase muscle strength, and increase physical activity. However, most of the studies have been carried out in the general population. The relationship between vitamin D status and physical performance in athletes has been studied in few studies. As a result, more studies are needed to fully characterize the mechanisms underlying the effect of calcitriol in human skeletal muscle tissue and to understand how these actions affect physical performance in athletes. 


\section{Giriş}

D vitamini son dönemlerde üzerinde oldukça fazla çalışılan, yağda eriyen vitaminler grubunda bulunan bir mikro besin ögesidir. Çalışmalar ilerledikçe, D vitamininin vücuttaki önemi oldukça belirgin hale gelmiş ve bu nedenle D vitamini eksikliğinin yaygınlığı son yıllarda yoğun bir şekilde incelenmiştir (Larson-Meyer ve Willis, 2010; Willis, Smith, Broughton ve Larson-Meyer, 2012). Yapılan çalışmalarda D vitaminin bağışıklık fonksiyonu, protein sentezi, inflamatuar yanı, hücresel büyüme, kas-iskelet sisteminin gelişmesi başta olmak üzere birçok metabolik olayda etkili olduğu görülmüştür (Kheiri ve diğerleri, 2018; Song ve diğerleri, 2018).

Sporcuların sedanter bireyler ile karşılaştırıldığında daha yüksek kemik mineral yoğunluğuna sahip olduğu bilinmektedir. Fiziksel aktiviteden kaynaklanan vücut yapısındaki herhangi bir farklılık, mekanik olarak o anki vücut yapısına uygun bir kemik yapısı oluşturmaktadır (Owens, Allison ve Close, 2018). Sporcularda yapılan kesitsel çalışmalar ya da müdahale çalışmalarında D vitamininin fiziksel performans üzerinde doğrudan etkisine dair tutarlı kanıt bulunmamaktadır. Farklı popülasyonlarda, özellikle yaşlı bireylerde yapılan çalışmalarda D vitaminin takviyesinin kemik sağlığını iyileştirdiği, yaralanma ve düşme riskini azalttı̆g 1 bildirilmektedir. Kas dokusunda keşfedilen D vitamini reseptörü (VDR) sonrasında sporcularda da D vitamini takviyesinin fiziksel performansını etkileyip etkilemediğini anlamak için çalışmalar başlatılmıştır (Geserick ve diğerleri, 2020; Iolascon, Moretti, De Sire, Calafiore ve Gimigliano, 2017; Owens ve diğerleri, 2018). Ancak oldukça sınırlı sayıda çalışma yapılmıştır. (Książek, Zagrodna ve Słowińska-Lisowska, 2019; Wiciński ve diğerleri, 2019). Bu sebeple bu çalışmada sporcularda D vitamininin fiziksel performans üzerindeki önemine ilişkin mevcut kanıtların özetlenmesi amaçlanmıştır. $\mathrm{Bu}$ amaçla PubMed, Google Scholar, ScienceDirect veritabanlarında 'Vitamin D and athlete', 'Vitamin D and athlete health', 'Vitamin D and athlete performans' ve 'D vitamini ve sporcu' anahtar kelimeleri ile tarama yapılarak yayınlanan araştırmalar çalışmanın amacına uygun şekilde incelenmiştir.

\section{D vitamini ve kas dokusu}

D vitamini, vücutta endokrin ve otokrin mekanizmaları aracılığıyla iki farklı şekilde işlev görür. İlk ve en iyi bilinen mekanizma, bağırsak kalsiyum emilimini ve osteoklast aktivitesini arttıran endokrin fonksiyonudur (Owens ve diğerleri, 2018). D vitamini kemik büyümesi, yoğunluğu ve yeniden şekillenmesi için gereklidir (DeLuca, 2004). D vitamini 
eksikliğinde vücut kalsiyum ihtiyacını karşılamak için kemik rezorpsiyonunu artırarak paratiroid hormonunu (PTH) aktive etmektedir. Bu durumda kemik dokusunda kayılara veya kemik yaralanmalarına neden olabilmektedir (Lappe ve diğerleri, 2008). Askerler ile yapılan bir çalışmada D vitamini durumunun pik kemik kütlesinin önemli bir belirleyicisi olduğu ayrıca $30 \mathrm{ng} / \mathrm{mL}$ 'nin altındaki 25 hidroksi D vitamini [25 (OH) D] seviyelerinin bu gruptaki stres kırığı riskini önemli ölçüde artırdığı bulunmuştur (Välimäki ve diğerleri, 2004). Deniz kuvvetleri mensubu olan 3700 kadın ile yapılan bir çalışmada sekiz hafta boyunca $800 \mathrm{IU} /$ gün D vitamini alan bireylerin stres kırıklarında plasebo grubuna göre \%20 daha düşük insidansa sahip olduğu görülmüştür (Lappe ve diğerleri, 2008). Fiziksel olarak aktif popülasyonlardaki bu çalışmalar, D vitamininin optimum kemik sağlığında kritik rol oynadığını göstermektedir.

D vitamininin biyolojik fonksiyonu, temel olarak 1,25-dihidroksivitamin D [1,25 $(\mathrm{OH})$ D]'nin spesifik olarak birkaç dokuda eksprese edilen VDR'ye bağlanarak aracılık etmesidir (Dattilo, Casale, Avventuroso ve Laganà, 2018). Ayrica, 1,25 (OH) D'nin doğrudan etkisi spesifik plazma membran reseptörleri yoluyla da mümkündür. Kas dokusu ile D vitamini ilişkisinin incelenmeye başlanmasının sebebi ise kas dokusunda keşfedilen D vitamini reseptörleridir (Dittfeld, Gwizdek, Koszowska ve Fizia, 2014).

D vitamininin diğer etki mekanizması otokrin yol aracılığgyladır. D vitamini bu etki mekanizması ile birçok temel metabolik sürecin gerçekleştirilmesinde aracılık etmektedir. Vücuttaki D vitamininin \%80'inden fazlası otokrin yol aracılığı ile etki gösterir (Heaney, 2008). Otokrin yol, gen ekspresyonu, protein sentezi, hormon sentezi, bağışıklık / enflamatuar yanıt, pozitif hücre döngüsü ve sentezi gibi temel metabolik süreçlerde rol oynar (LeBoff ve diğerleri, 2020). Yapılan çalışmalarda D vitamini eksikliğinde, hücrenin patolojik ve fizyolojik sinyallere yeterince yanıt verme yeteneğinin bozulduğu görülmüştür (Heaney, 2008; Ogan ve Pritchett, 2013).

D vitamininin iskelet kas dokusu üzerindeki etkisi otokrin yol ile gerçekleşmektedir. Kas dokusunda bulunan VDR'lerin keşfedilmesi ile kas-iskelet sistemi sağlığ 1 ve D vitamini ilişkisi çalışılmaya başlanmıştır. Yapılan çalışmalarda D vitamininin kas dokusu üzerindeki etkilerinin iki farklı mekanizma üzerinden gerçekleştirebileceği bildirilmektedir (Ceglia ve Harris, 2013). Önerilen ilk mekanizma 1,25 (OH) D'nin kas hücre içerisindeki VDR'ler aracılığı ile doğrudan etki etmesidir. İkinci mekanizma ise D vitamininin kas kasılmasında etkili kalsiyum bağlanma bölgelerinin etkinliğini veya sayısını artırarak sarkoplazmik retikulumdaki kalsiyum taşınmasını etkilemesi ile dolaylı etki etmesidir (Angeline, Gee, 
Shindle, Warren ve Rodeo, 2013). Çalışmalar özellikle D vitamininin kalsiyumun hücre içi ve hücre dışı seviyelerinin düzenlenmesine etkisinin, fosforlu bileşiklerin homeostazının ve PTH salınımının uyarılmasının kas kuvveti üzerinde etki ettiğini göstermektedir (Buitrago, Pardo ve Bolant, 2013). Aynı zamanda D vitamininin belirli kas proteinlerinin sentezini indüklediği dolayısı ile kas kütlesinin ve gücünün artmasına neden olabileceği bildirilmektedir. Bunların yanında D vitamini tip II kas liflerinin çapını ve sayısını da etkileyebilmektedir. D vitamini eksikliğinin intramyonükleer VDR gen ekspresyon düzeyinin azaltılmasına ve tip IIA kas lifi atrofisinin neden olduğu myopatiye katkıda bulunabileceği bildirilmektedir (Dzik ve Kaczor, 2019; Todd ve diğerleri, 2016; Todd, Pourshadidi, Macsorley, Madigan ve Magee, 2015).

\section{D vitamini ve fiziksel performans}

D vitamini dünya çapında sporcular arasında en sık kullanılan besin takviyelerinden biridir (Madden, Shearer, Legg ve Pamel, 2018). D vitamini ve fiziksel performans ile ilgili çalışmalar oldukça çelişkili sonuçlar vermektedir. Mevcut literatür, D vitamini takviyesinin kaslardaki VDR sayısını ve kas performansını artırabileceğini, kırık riskini ise azaltabileceğini göstermektedir, ancak bu sonuçlar esas olarak yaşlılarda bildirilmiştir. Sporcularda branşların oldukça farklı olması, bireysel yanıtlardaki farklılıklar ve çalışma metodolojilerinin farklı olması sebebi ile kesin sonuç elde edilememektedir (Close, Hamilton, Philp, Burke ve Morton, 2016; Todd ve diğerleri, 2017).

Farklı branşlardan 61 sporcu ve 30 sağlıklı ancak sporcu olmayan birey ile yürütülen plasebo kontrollü bir çalışmada sporculara 8 hafta boyunca günde 5000 IU D vitamini takviyesi yapılmıştır. Çalışma sonunda D vitamini takviyesi ile kas-iskelet sistemi performansı arasında pozitif yönde bir ilişki bulunmuştur (Close ve diğerleri, 2013). Judo sporcuları ile yapılan bir çalışmada 25 sporcu çalışmaya dahil edilmiştir. Sporcuların \%80'inin serum $25(\mathrm{OH})$ D durumunun $<30 \mathrm{ng} / \mathrm{mL}$ olduğu ve serum $25(\mathrm{OH}) \mathrm{D}$ durumu ile el kavrama kuvvetinin pozitif ilişkili olduğu görülmüştür (Książek, Dziubek, Zagrodna ve Słowińska-Lisowska, 2018).

D vitamininin, kas protein sentezi, hücre farklılaşması ve hücre proliferasyonunun düzenlenmesi, ayrıca fosfolipid metabolizmasını modüle ederken kalsiyum ve fosfatın kas hücre zarları boyunca taşınması yoluyla da kas fonksiyonunu etkilediği bilinmektedir (Zhang, Quan ve Cao, 2019). Randomize çift kör plasebo kontrollü bir çalışmada 4 ay boyunca $4000 \mathrm{IU} / g u ̈ n ~ D$ vitamini takviyesinin kas lifi kesit alanını $\% 10$ ve VDR 
konsantrasyonunu \%30 artırdığı görülmüştür (Ceglia ve diğerleri, 2013). Bir başka çalışmada bireylere 6 ay boyunca $20 \mu \mathrm{g} / \mathrm{gün} \mathrm{D}$ vitamini takviyesi yapılmış, çalışma sonunda D vitamini takviyesinin kas performansını artırdığg ve düşme riskini azalttığ 1 görülmüştür (Iolascon ve diğerleri, 2017). Ancak bu çalışmaların büyük kısmı yaşlı bireyler üzerinden yürütülmüş olup sporcular üzerinde yapılmış çalışma oldukça sınırlıdır. Farklı branşlardan sporcular ile yürütülen takviye çalışmalarının sonuçları oldukça çelişkilidir. Sporcularda D vitamini takviyesinin alt ve üst ekstremite kas kuvvetine etkisinin incelendiği bir meta analiz çalışmasında sekiz randomize kontrollü çalışma incelenmiştir. Çalışma sonunda D vitamini takviyesinin sporcularda alt ekstremite kas kuvvetini olumlu etkilediği, ancak üst ekstremite kas kuvvetini etkilemediği görülmüştür. Çalışmalarda serum D vitamini seviyesini belirleyen yöntemlerin ve kas kuvvetini ölçen yöntemlerin farklı olması çalışma sonuçlarının tutarsız olmasına sebep olmuştur (Zhang ve diğerleri, 2019).

\section{Sporcularda D vitamini önerileri}

D vitamininin birincil kaynağı güneş ışınlarıdır ve besinlerle alınan D vitamini oldukça sınırlıdır. Besinlerle alınan D vitaminin sınırlı olması D vitamini eksikliğinin önemli bir sebebini oluşturmaktadır. Bu sebeple güneş ışığı ile alınan D vitamini ve takviyeler serum seviyelerinin korunması için oldukça önemli kaynaklardır (Aydın, Dinçel, Arıkan, Taş ve Deniz, 2019). D vitamini durumunun belirlenmesinde en sık kullanılan yöntem 25 (OH) D seviyesinin belirlenmesidir. Ancak $25(\mathrm{OH})$ D kesim noktaları kılavuzlara göre oldukça farklılık göstermektedir. En son yönergelere uygun olarak, serum $25(\mathrm{OH}) \mathrm{D}$ seviyeleri için normal aralıklar 30-50 ng/mL (75-125 nmol/L) veya $40-60 \mathrm{ng} / \mathrm{mL}(100-150 \mathrm{nmol} / \mathrm{L})$ olarak tanımlanmaktadır. Birçok uluslararası kılavuz serum $25(\mathrm{OH})$ D konsantrasyonunun $<25 / 30$ nmol/L artmış riskin göstergesi olduğu ancak bazı özel klinik durumlarda kesim noktalarında farklılık olabileceği bildirilmiştir (Pludowski ve diğerleri, 2018; Institute of Medicine [IOM], 2011). Yapılan bir çalışmada sporcular için D vitamini alımlarının bireysel olarak değerlendirilmesi gerektiği, güneş 1şığına maruz kalma süresi $<20$ dakika olan, $<30$ • veya $>60$ • enlemlerinde yaşayan, serum D vitamini düzeyi $<75 \mathrm{nmol} / \mathrm{mL}$ olan sporcuların 2000 4000 IU/gün D vitamini almaları önerilmiştir. Ancak bireysel parametrelere ve branşlara göre uygun gereksinimlerin belirlenmesinin önem taşıdığı bildirilmiştir (Owens ve diğerleri, 2018).

Sporculardaki D vitamini eksikliği prevalansı çalışmalarda farklılık göstermektedir ancak çoğu araştırmacı tarafından sporcuların D vitamini durumu açısından değerlendirilmeleri ve optimal $25(\mathrm{OH})$ D seviyesi olarak önerilen $>40 \mathrm{ng} / \mathrm{mL}$ 'yi korumak 
için alım önerileri verilmesi gerektiği düşünülmektedir (Heaney, 2008; Ogan ve Pritchett, 2013). Ancak sporcular için ayrı olarak önerilen D vitamini alım düzeyi uluslararası kılavuzlar tarafından henüz belirlenmemiştir. Farklı popülasyonlar için D vitamini alım önerilerinin belirlenmesinin önemli olduğu vurgulanmaktadır (Książek ve diğerleri, 2019).

\section{Sonuç}

D vitamini, sporcularda kemik sağlığının korunması ve stres faktörlerinin önlenmesi için önemli bir mikro besin ögesidir. Bunun yanında D vitamini elektrolit metabolizmasının, protein sentezinin, gen ekspresyonunun ve bağışıklık fonksiyonunun düzenlenmesine de yardımcı olmaktadır. Bu özelliklerin tüm bireyler için geçerli olmakla birlikte özellikle son dönemlerde kas dokusunda keşfedilen VDR'ler sebebi ile sporcularda büyük önem taşıdığ1 bildirilmiştir.

Hem sporcu sağlığı hem de sporcuların fiziksel performansı için serum D vitamininin optimal düzeyini sağlamak oldukça önemlidir. Sporcularda serum D vitaminin optimal seviyede olmasının fiziksel performans üzerinde olumlu etki ettiğine dair çalışmalar bulunsa da çalışmaların metodolojilerinin oldukça farklı olması, farklı branşlardan sporcular ile çalışılması ve serum D vitaminin seviyesinin belirlenmesi için farklı kesim noktalarının kullanılması sebebi ile mevcut kanıtların yetersiz olduğu söylenebilir. Bu sebeple ileride; sporcular için uluslararası düzeyde önerilen D vitamini gereksinimleri belirlenmeli, sporcu sağlığı ve fiziksel performansı için önemli bir etkisi olduğu düşünülen D vitamini ile ilgili farklı branşlardan sporcular ile uluslararası otoriteler tarafından kabul edilmiş serum D vitamini kesim noktaları dikkate alınarak çift kör, randomize kontrollü ve büyük örneklemler ile araştırmalar yapılmalıdır. Böylelikle sporcular gibi spesifik bir grup için kas dokusundaki önemli etkileri olduğu düşünülen $\mathrm{D}$ vitamini ile ilgili mevcut kanıtların artırılması ve literatüre kazandırılması sağlanmalıdır.

\section{Kaynaklar}

Angeline, M. E., Gee, A. O., Shindle, M., Warren, R. F. ve Rodeo, S. A. (2013). The effects of vitamin D deficiency in athletes. American Journal of Sports Medicine, 41(2), 461-464.

Aydın, C. G., Dinçel, Y. M., Arıkan, Y., Tas, S. K. ve Deniz, S. (2019). The effects of indoor and outdoor sports participation and seasonal changes on vitamin D levels in athletes. SAGE Open Medicine, 7, 16.

Buitrago, C., Pardo, V. G. ve Boland, R. (2013). Role of VDR in 1alpha,25-dihydroxyvitamin D3-dependent non-genomic activation of MAPKs, Src and Akt in skeletal muscle cells. The Journal of Steroid Biochemistry and Molecular Biology, 136, 125-130. 
Ceglia, L. ve Harris, S.S. (2013). Vitamin D and its role in skeletal muscle. Calcified Tissue International, 92(2), 151-162.

Ceglia, L., Niramitmahapanya, S., Da Silva Morais, M., Rivas, D. A., Harris, S. S. ve Bischo-Ferrari, H. (2013). A randomized study on the effect of vitamin D3 supplementation on skeletal muscle morphology and vitamin D receptor concentration in older women. The Journal of Clinical Endocrinology and Metabolism, 98(12), 1927-1935.

Close, G. L., Hamilton, D. L., Philp, A., Burke, L. L., ve Morton, J. P. (2016). New strategies in sport nutrition to increase exercise performance. Free Radical Biology and Medicine, 98, 144-158.

Close, G. L., Russell, J., Cobley, J. N., Owens, D. J., Wilson, G., ve Gregson, W. (2013). Assessment of vitamin $\mathrm{D}$ concentration in non-supplemented professional athletes and healthy adults during the winter months in the UK: Implications for skeletal muscle function. Journal of Sports Sciences, 31(4), 344-353.

Dattilo, G., Casale, M., Avventuroso, E. ve Laganà, P. (2018). Vitamin D dietary supplementation: Relationship with chronic heart failure. Journal of AOAC International, 101(4), 939-941.

DeLuca, H. F. (2004). Overview of general physiologic features and functions of vitamin D. The American Journal of Clinical Nutrition, 80(6 Suppl), 1689-96.

Dittfeld, A., Gwizdek, K., Koszowska, A. ve Fizia, K. (2014). Multidirectional effect of vitamin D. Annales Academiae Medicae Silesiensis, 68, 1.

Dzik, K. P. ve Kaczor, J. J. (2019). Mechanisms of vitamin D on skeletal muscle function: oxidative stress, energy metabolism and anabolic state. European Journal of Applied Physiology, 119(4), 825-839.

Geserick, M., Vogel, M., Eckelt, F., Schlingmann, M., Hiemisch, A., ve Baber, R. (2020). Children and adolescents with obesity have reduced serum bone turnover markers and 25-hydroxyvitamin D but increased parathyroid hormone concentrations- Results derived from new pediatric reference ranges. Bone, 132, 115124.

Heaney, R. P. (2008). Vitamin D in health and disease. Clinical journal of the American Society of Nephrology: CJASN, 3(5), 1535-1541.

Institute of Medicine (2011). Committee to Review Dietary Reference Intakes for Vitamin D and Calcium. Washington (DC): National Academies Press (IOM).

Iolascon, G., Moretti, A., De Sire, A., Calafiore, D. ve Gimigliano, F. (2017). Effectiveness of Calcifediol in Improving Muscle Function in Post-Menopausal Women: A Prospective Cohort Study. Advances in Therapy, 34(3), 744-752.

Kheiri, B., Abdalla, A., Osman, M., Ahmed, S., Hassan, M. ve Bachuwa, G. (2018). Vitamin D deficiency and risk of cardiovascular diseases: a narrative review. Clinical Hypertension, 24, 9.

Książek, A., Zagrodna, A. ve Słowińska-Lisowska, M. (2019). Vitamin D, Skeletal Muscle Function and Athletic Performance in Athletes- A Narrative Review. Nutrients, 11(8), 1800.

Książek, A., Dziubek, W., Pietraszewska, J. ve Słowińska-Lisowska, M. (2018). Relationship between 25(OH)D levels and athletic performance in elite Polish judoists. Biology of Sport, 35(2), 191-196.

Lappe, J., Cullen, D., Haynatzki, G., Recker, R., Ahlf, R. ve Thompson, K. (2008). Calcium and vitamin d supplementation decreases incidence of stress fractures in female navy recruits. Journal of Bone and Mineral Research, 23(5), 741-749.

Larson-Meyer, D. E. ve Willis, K. S. (2010). Vitamin D and athletes. Current Sports Medicine Reports, 9(4), 220-226. 
LeBoff, M. S., Chou, S. H., Murata, E. M., Donlon, C. M., Cook, N. R. ve Mora, S. (2020). Effects of Supplemental Vitamin D on Bone Health Outcomes in Women and Men in the Vitamin D and OmegA3 Trial (VITAL). Journal of Bone and Mineral Research, 0(0), 1-11.

Madden, R. F., Shearer, J., Legg, D. ve Parnell, J. A. (2018). Evaluation of dietary supplement use in wheelchair rugby athletes. Nutrients, 10(12), 1958.

Ogan, D. ve Pritchett, K. (2013). Vitamin D and the Athlete: Risks, Recommendations, and Benefits. Nutrients, 5(6), 1856-1868.

Owens, D. J., Allison, R. ve Close, G. L. (2018). Vitamin D and the Athlete: Current Perspectives and New Challenges. Sports Medicine, 48(Suppl 1), 3-16.

Pludowski, P., Holick, M. F., Grant, W. B., Konstantynowicz, J., Mascarenhas, M. R. ve Haq, A. (2018). Vitamin D supplementation guidelines. The Journal of Steroid Biochemistry and Molecular Biology, $175,125-135$.

Song, T. J., Chu, M. K., Sohn, J. H., Ahn, H. Y., Lee, S. H. ve Cho, S. J. (2018). Effect of Vitamin D Deficiency on the Frequency of Headaches in Migraine. Journal of Clinical Neurology (Seoul, Korea), 14(3), 366373.

Todd, J. J., Pourshahidi, L. K., McSorley, E. M., Madigan, S. M. ve Magee, P. J. (2015). Vitamin D: recent advances and implications for athletes. Sports Medicine, 45(2), 213-229.

Todd, J. J., Madigan, S., Pourshahidi, K., McSorley, E., Laird, E. ve Healy, M. (2016). Vitamin D status and supplementation practices in Elite Irish Athletes: An update from 2010/2011. Nutrients, 8(8), 485.

Todd, J. J., McSorley, E. M., Pourshahidi, L. K., Madigan, S. M., Laird, E. ve Healy, M. (2017). Vitamin D3 supplementation using an oral spray solution resolves deficiency but has no effect on VO2 max in Gaelic footballers: results from a randomised, double-blind, placebo-controlled trial. European Journal of Nutrition, 56(4), 1577-1587.

Välimäki, V. V., Alfthan, H., Lehmuskallio, E., Löyttyniemi, E., Sahi, T. ve Stenman, U. H. (2004). Vitamin $\mathrm{D}$ status as a determinant of peak bone mass in young Finnish men. The Journal of Clinical Endocrinology and Metabolism, 89(1), 76-80.

Wiciński, M., Adamkiewicz, D., Adamkiewicz, M., Śniegocki, M., Podhorecka, M. ve Szychta, P. (2019). Impact of Vitamin D on Physical Efficiency and Exercise Performance-A Review. Nutrients, 11(11), 2826.

Willis, K. S., Smith, D. T., Broughton, K. S. ve Larson-Meyer, D. E. (2012). Vitamin D status and biomarkers of inflammation in runners. Open Access Journal of Sports Medicine, 3, 35-42.

Zhang, L., Quan, M. ve Cao, Z. B. (2019). Effect of vitamin D supplementation on upper and lower limb muscle strength and muscle power in athletes: A meta-analysis. PLOS ONE, 14(4), e0215826. 